\title{
Potential of new tetraploid germplasm in Russian wildrye
}

\author{
K.H. ASAY, D.A. JOHNSON, K.B. JENSEN, W.M.SARRAJ, AND D.H. CLARK
}

\begin{abstract}
Authors are: Research Geneticist, Plant Physiologist, Research Geneticist, Visiting Scientist, and Animal Scientist, USDAAgricultural Research Service, Forage and Range Research Laboratory, Utah State University, Logan, Utah 84322-6300. Cooperative investigations of USDA-Agricultural Research Service and the Utah Agricultural Experiment Station, Logan, Utah 84322 .
\end{abstract}

\begin{abstract}
Induced and natural tetraploids have been proposed as promising sources of germplasm in breeding programs to improve Russian wildrye [Psathyrostachys juncea (Fisch.) Nevski]. Studies were conducted under semiarid conditions to evaluate the potential of tetraploid $(2 n=4 x=28)$ Russian wildrye germplasm recently obtained from Kazakhstan. The tetraploids had significantly heavier seeds, greater seedling vigor, and they were significantly taller, and had longer and wider leaves than standard diploid $(2 \mathrm{n}=2 \mathrm{x}=14)$ cultivars. Carbon isotope discrimination, which has been negatively correlated with water-use efficiency in cool-season grasses, was significantly lower in the tetraploid accessions than the diploid cultivars. Dry matter and seed yield of these unselected tetraploid accessions were superior to the diploid cultivar Vinall and equivalent to more recently developed diploid cultivars, Bozoisky-Select and Syn-A. In general, relative phenological development and forage quality of the tetraploid populations did not differ significantly from the diploid cultivars; however, water content, which has been associated with greater succulence, was significantly higher in the tetraploid accessions. Significant variation was found among entries within ploidy levels for most characters indicating that genetic variability is available for additional improvement through selection. Results indicate that these tetraploid accessions can be used in the development of promising breeding populations and support earlier conclusions that tetraploid germplasm should receive emphasis in future Russian wildrye breeding programs.
\end{abstract}

Key Words: Psathyrostachys juncea, carbon isotope discrimination, water-use efficiency, seed yield, seedling vigor, forage quality, forage yield

Russian wildrye [Psathyrostachys juncea (Fisch.) Nevski], a cool-season bunchgrass, provides excellent grazing for livestock and wildlife on rangelands of the Northern Great Plains and the Intermountain Region of North America. The species is native to the steppe and desert regions of Eurasia and, although introduced into the USA in 1927, its potential in range seeding programs was not recognized until the 1950s (Hanson 1972). Russian wildrye is valued as a source of forage during the early spring, and its dense basal leaves also retain their nutritive value better than those of most other temperate range grasses during the late summer and fall (Knipfel and Heinrichs 1978). It is resistant to drought and persists under adverse range conditions; however, it has poor

Approved as Journal Paper No. 4683. The authors acknowledge the technical assistance provided by W.T. Hansen III and K.J. Connors.

Manuscript accepted 14 Oct. 1995 seedling vigor and satisfactory stands are often difficult to obtain. Secdling vigor has been positively correlated with individual seed weight, and screening procedures based on seed weight and emergence from deep seedings have been effectively used in breeding programs to improve seedling vigor in Russian wildrye (Asay and Johnson 1980, Berdahl and Barker 1984, Lawrence 1979).

Bingham et al. (1994) proposed that increased vigor of tetraploid alfalfa compared to diploid forms may be associated with greater complementary gene interaction (nonallelic gene interaction or epistasis) at the tetraploid level. Dewey (1980) reviewed the effects and significance of ploidy level in plant breeding programs. He concluded that induced polyploidy usually results in increased cell size and reduced fertility and suggested that polyploid breeding would be most appropriate in species with a low chromosome number and those that are harvested primarily for their vegetative parts. It follows that many perennial forage crops would be well suited to polyploid breeding. As a perennial forage grass with a typical chromosome number of $2 n=$ $2 x=14$, Russian wildrye appears to be an excellent candidate for polyploid breeding, and findings to date offer some basis for optimism. Induced tetraploids of Russian wildrye reportedly have larger seeds and better seedling vigor than their diploid counterparts (Berdahl and Barker 1991, Lawrence et al. 1990). Tetraploid breeding populations have been developed through induced polyploidy and plant exploration by USDA-ARS breeding programs at Logan, Utah (Asay 1992), and Mandan, North Dakota (Berdahl and Barker 1991), and by Agriculture and Agri.Food Canada at Swift Current, Saskatchewan (Lawrence et al. 1990). The tetraploid cultivar Tetracan was developed from induced tetraploid germplasm and licensed in 1988 by Agriculture and Agri.-Food Canada at Swift Current. In evaluation trials in the Northern Great Plains, Tetracan had larger spikes and seeds and wider leaves than diploid cultivars (Lawrence et al. 1990). Tetracan also was found to produce fewer but larger tillers and longer roots than diploid cultivars in the seedling stage of development (Jefferson 1993).

Water-use efficiency is prerequisite of a productive grass on arid and semiarid rangelands. Evaluation of grass germplasm for water-use efficiency on the basis of actual determinations of dry matter produced per unit of water transpired is extremely laborious and is not feasible for large breeding populations. Carbon isotope discrimination has been negatively correlated with water-use efficiency in several $C_{3}$ species (Farquhar et al. 1989) and has been proposed as a criterion for evaluating genetic variation for water-use efficiency in cool-season grasses (Johnson et al. 1990). 
Ten tetraploid accessions of Russian wildrye, recently obtained from Kazakhstan, were compared with the tetraploid cultivar Tetracan and standard diploid cultivars. Objectives were to determine the potential of these germplasm resources in a breeding program to improve the seedling vigor, productivity, water-use efficiency, and forage quality of Russian wildrye.

\section{Materials and Methods}

\section{Plant Materials}

Ten tetraploid accessions originally from Kazakhstan were obtained from the N.I. Vavilov Institute of Plant Industry (VIR), St. Petersburg, Russia. The accessions were entered in the National Plant Germplasm System (NPGS) and assigned PI numbers 565063 to 565072 . The tetraploid cultivar Tetracan was released in 1988 by Agriculture and Agri.-Food Canada, Swift Current, Sask. Two diploid cultivars, Bozoisky-Select and Vinall, a diploid experimental strain (Syn-A) and a common diploid strain were included as checks. Bozoisky-Select was released by the USDA-ARS in 1984 in cooperation with the Utah Agricultural Experiment Station and USDA-NRCS (Asay et al. 1985). Vinall was developed by USDA-ARS at Mandan, N.D. and relcased for seed increase in 1960 (Rogler and Schaaf 1963). The experimental strain, Syn-A, was developed by the USDAARS at Logan, Utah largely on the basis of improved seedling vigor under drought. The diploid strain, Common, was of obscure origin.

\section{Field Design}

Two studies were conducted on a site $2 \mathrm{~km}$ south of Logan, Utah $\left(41^{\circ} 45^{\prime} \mathrm{N}, 111^{\circ} 48^{\prime} \mathrm{W}\right)$ at an altitude of $1,350 \mathrm{~m}$. The first experiment (Experiment A), which was established in April 1989, consisted of 3 tetraploid accessions that had been recieved from Kazakhstan at that time, Tetracan, Bozoisky-Select, Vinall, Syn-A, and Common. Experiment $B$ was established in an adjacent field site in April 1990 and consisted of 7 additional tetraploid accessions received after Experiment $A$ was established and the same diploids with the exception of Common. Soil for both experiments was a Nibley silty clay loam that was classified as a fine, mixed mesic Aquic Argiustoll. The plots received an annual autumn application of $45 \mathrm{~kg} \mathrm{~N} \mathrm{ha}^{-1}$, and no supplemental irrigation was added. Precipitation received from October through September was $334,408,330$, and $558 \mathrm{~mm}$ in 1989-90, 1990-91, 1991-92, and 1992-93, respectively. Seedlings were established in the greenhouse prior to transplanting in the field. Plots consisted of 10 plants on 1-m centers, and both experiments were arranged in a randomized complete block design with 4 replications.

\section{Evaluation Criteria \\ Experiment $A$}

In 1990, 1 year after transplanting, determinations were made of carbon isotope discrimination $(\Delta)$, seed yield, 100 -seed weight, and seedling vigor. For determinations of $\Delta$, the 2 most fully expanded leaves werc sampled from separate tillers on each plant at the heading stage of plant development. Samples were sealed in a paper envelope, and dried at $70^{\circ} \mathrm{C}$ for 36 hours. The dried leaves were bulked within plots and ground to pass through a 0.5 $\mathrm{mm}$ screen in a Wiley mill, and values for $\Delta$ were determined with an isotope ratio mass spectrometer (SIRA 10; Fisons Instruments, Valencia, Calif.), as described by Read et al. (1992). Seed yield and 100-seed weights were obtained in 1991 and
1992. Seedling vigor was evaluated on seed produced in 1991 and 1992 based on emergence from a 7.6-cm depth as described by Asay and Johnson (1980).

\section{Experiment $B$}

In 1991, 1 year after transplanting, determinations were made of dry matter yield, leaf width, leaf length, plant height, forage quality, and $\Delta$. Plots were harvested for determination of dry matter yield on 23 May (first 5 plants in each plot) and 17 June (second 5 plants) 1991, 22 June 1992, and 15 June 1993. With the exception of the first harvest in 1991, which was made at the boot stage, all harvests were made at the post-anthesis stage, and dry weights were expressed as $\mathrm{kg} \mathrm{ha}^{-1}$. Samples for evaluation of forage quality were taken during the 1992 and 1993 harvests, dried at $60^{\circ} \mathrm{C}$ and ground first in a Wiley mill and then a cyclone mill to pass through a 1-mm screen. Neutral detergent fiber (NDF), acid detergent fiber (ADF), dry. matter digestibility (IVDMD), and crude protein were determined by near-infrared-reflectance spectroscopy (NIRS) according to procedures described by Marten et al. (1989). Leaf width and leaf length were determined from the second oldest leaf of a tiller at the heading stage of plant development. Five leaves from each of 10 plants per plot were measured. Width was determined at the widest point on the leaf, and length was measured from the collar to the tip of the leaf. Determinations of $\Delta$ were made on leaf samples in 1992 and 1993 as described under Experiment $A$.

Phenological differences were recorded at the boot, head, and inflorescence stages of plant development in 1994 using a rating scale of 1 to 5 , where $1=$ early and $5=$ late. The phenology index was computed as the sum of ratings across stages of plant development.

Data were analyzed within and across years using a general linear model (GLM, SAS Institute, Cary, N.C.). Because the plot randomization of these perennial grasses was not changed each year, mean squares for year and ploidy $X$ year were tested with the replication $X$ year and replication $X$ ploidy $X$ year mean squares, respectively. The Waller-Duncan test was used to separate means of all entries in Experiment $A$, and single degree of freedom contrasts were used in Experiment B to compare tetraploid means with each of the diploid entries.

\section{Results and Discussion}

\section{Experiment $A$}

Significant differences were found among entries for all traits measured during 1990 through 1992 (Tables 1 and 2). Based on $\Delta$ values, the tetraploid accessions had significantly better wateruse efficiency than the diploids. The $\Delta$ values ranged from 18.1 to $18.3 \%$ in the tetraploid accessions compared to a range of 19.5 to $20.0 \%$ in the diploids. Although Tetracan had a significantly higher $\Delta$ than the tetraploid accessions, $\Delta$ for this tetraploid cultivar was significantly lower than the diploid entries.

Seed yield of the Russian wildrye entries differed significantly ( $P<0.01$ ); however, no consistent trend was evident for the 2 ploidy levels. One diploid strain, Common, produced significantly more seed than all tetraploid entries. The tetraploid entries had significantly heavier seed (100-seed weight) than the diploids, although seed of 2 accessions, AJC 539 and AJC 538, was lighter than Tetracan. Differences in seed weight were reflected in results from seedling vigor trials. All tetraploids had a higher rate of emergence than the diploids, and the 3 tetraploid accessions 
Table 1. Mean squares from analyses of variance for carbon isotope discrimination $(\Delta)$, seed yield, 100 -seed weight, and rate of seedling emergence of Russian wildrye diploid and tetraploid strains and cultivars, Experiment A.

\begin{tabular}{lllccc}
\hline \hline Source & Df & $\Delta \dagger$ & $\begin{array}{c}\text { Seed } \\
\text { yield }\end{array}$ & $\begin{array}{c}\text { 100-seed } \\
\text { weight }\end{array}$ & $\begin{array}{c}\text { Rate of } \\
\text { emergence } \ddagger\end{array}$ \\
\hline & & $(\%)$ & $\left(\mathrm{g} \mathrm{m}^{-1}\right)$ & $(\mathrm{g})$ & ${\text { (Seedlings } \mathrm{d}^{-1)}}$ \\
Entry & 7 & $2.175^{* *}$ & $7818^{* *}$ & $0.740^{* *}$ & $5.559^{* *}$ \\
Year & 1 & & 719 & $0.033^{*}$ & 2.634 \\
Entry X Year & 7 & & 692 & 0.004 & $4.443^{*}$ \\
\hline
\end{tabular}

$\dagger$ In Experiment A, $\Delta$ was determined in 1990, whereas seed yield, 100-seed weight, and rate of emergence were determined in 1990 and 1991.

\# Seedling emergence was from $7.6-\mathrm{cm}$ depth and rate of emergence determined according to Maguire (1962).

were equivalent to Tetracan in this regard. The entry $X$ year interaction was significant $(P<0.05)$ for rate of emergence; however, this was due to the wide fluctuation of one diploid strain, Syn-A, across the 2 years.

\section{Experiment $B$}

As in Experiment A, entries differed significantly for carbon isotope discrimination, and differences were relatively consistent across years as indicated by the nonsignificant entry $X$ year interaction (Table 3). The mean $\Delta$ value for the 10 tetraploid accessions was significantly $(P<0.01)$ lower than each of the 3 diploid cultivars during each year and in the analysis of the data combined across years. For example, in the data combined across years, $\Delta$ ranged from 16.8 to $17.7 \%$ and averaged $17.2 \%$ for the 10 tetraploid accessions compared to mean values of $17.9 \%$ for Bozoisky-Select and $18.1 \%$ for Syn-A and Vinall. The $\Delta$ value for the tetraploid cultivar Tetracan was not significantly different from the tetraploid accessions.

Differences among grass entries for dry matter yield were nonsignificant except in 1993 (Table 3). The entry $X$ year interaction was significant $(\mathrm{P}<0.05)$, therefore only dry matter yield data from within each of the 3 years are presented. In 1993, single degree of freedom contrasts revealed that dry matter yield of the tetraploid accessions was significantly greater than the diploid cultivar Vinall $(P<0.01)$ but similar to the other 3 check entries included in the study (Table 4). The range in dry matter yield

Table 2. Carbon isotope discrimination $(\Delta)$, seed yield, 100-seed weight, and rate of seedling emergence of Russian wildrye diploid and tetraploid strains and cultivars, Experiment A.

\begin{tabular}{|c|c|c|c|c|c|}
\hline Entry & Ploidy & $\Delta \dagger$ & $\begin{array}{l}\text { Seed } \\
\text { yield }\end{array}$ & $\begin{array}{c}100 \text {-seed } \\
\text { weight }\end{array}$ & $\begin{array}{c}\text { Rate of } \\
\text { emergence }\end{array}$ \\
\hline & & $(\% o)$ & $\left(\mathrm{g} \mathrm{m}^{-1}\right)$ & $(\mathrm{g})$ & (Seedlings $\mathrm{d}^{-1}$ ) \\
\hline AJC538 & $4 x$ & $18.1 \mathrm{~d} \S$ & $26.78 \mathrm{c}$ & $0.50 \mathrm{c}$ & $5.69 \mathrm{abc}$ \\
\hline AJC539 & $4 x$ & $18.3 \mathrm{~d}$ & $36.45 \mathrm{bc}$ & $0.54 \mathrm{~b}$ & $6.25 \mathrm{ab}$ \\
\hline AJC540 & $4 x$ & $18.3 \mathrm{~d}$ & $44.03 \mathrm{~b}$ & $0.56 \mathrm{ab}$ & $6.37 \mathrm{ab}$ \\
\hline Tetracan & $4 x$ & $18.8 \mathrm{c}$ & $36.93 \mathrm{bc}$ & $0.57 \mathrm{a}$ & $6.67 \mathrm{a}$ \\
\hline Bozoisky & $2 x$ & $19.6 \mathrm{~b}$ & $45.15 \mathrm{~b}$ & $0.34 \mathrm{e}$ & $4.61 \mathrm{c}$ \\
\hline Common & $2 \mathrm{x}$ & $19.6 \mathrm{~b}$ & $61.66 \mathrm{a}$ & $0.41 \mathrm{~d}$ & $4.84 \mathrm{c}$ \\
\hline Syn-A & $2 \mathrm{x}$ & $19.5 \mathrm{~b}$ & $38.72 b c$ & $0.37 \mathrm{e}$ & 5.26 bc \\
\hline Vinall & $2 \mathrm{x}$ & $20.0 \mathrm{a}$ & $47.02 \mathrm{ab}$ & $0.35 \mathrm{e}$ & $4.57 \mathrm{c}$ \\
\hline
\end{tabular}

tIn Experiment A, $\Delta$ was determined in 1990, whereas seed yield, 100-seed weight, and rate of emergence were determined in 1990 and 1991.

F Seedling emergence was from 7.6-cm depth and rate of emergence determined according to Maguire (1962).

$\S$ Values in columns followed by same letter are not significant at 0.05 probability level according to Waller Duncan. among the tetraploid accessions $\left(2,889\right.$ to $\left.3,953 \mathrm{~kg} \mathrm{ha}^{-1}\right)$ indicated that substantial variation was available to select for genetic improvement in this trait.

The tetraploid accessions were significantly taller and had significantly $(P<0.01)$ wider and longer leaves than the diploid entries (Tables 3 and 4). In the analyses of data across 3 years, mean plant height of the tetraploid accessions was $123 \mathrm{~cm}$ compared to 117 $\mathrm{cm}$ for Bozoisky-Select, $117 \mathrm{~cm}$ for Syn-A, and $105 \mathrm{~cm}$ for Vinall. Plant height of the tetraploid accessions also was significantly greater than Tetracan $(114 \mathrm{~cm})$. Differences in leaf width and length were particularly noteworthy in 1993, where mean values for the tetraploid accessions were significantly $(P<0.01)$ greater than each of the diploid and tetraploid check entries.

Although phenological differences among entries were significant, differences were not consistent between the tetraploids and diploids. The tetraploid accessions were significantly later than the diploid cultivar Vinall and the tetraploid cultivar Tetracan, but phenological development of the tetraploid accessions was similar to Bozoisky-Select and Syn-A (data not shown).

Differences between the tetraploid accessions and the diploid check entries were generally nonsignificant for NDF, ADF, protein content, and IVDMD (data not shown). The tetraploid accessions, however, had significantly higher water content than the diploid accessions in most comparisons made within each of the 3 years and in the combined analysis of the data. Water content has been positively associated with increased ploidy levels in forage grasses (Sullivan 1944) and may be indicative of greater succulence.

\section{Implications}

The objectives of this study were primarily to evaluate the potential of new sources of tetraploid germplasm in Russian

Table 3. Mean squares from analyses of variance for carbon isotope discrimination $(\Delta)$, dry matter yield, plant height, leaf width, and leaf length, Experiment $B$.

\begin{tabular}{|c|c|c|c|}
\hline & Entry & Year & Entry $\times$ Year \\
\hline \multicolumn{4}{|c|}{ Carbon isotope discrimination (\%o) } \\
\hline $1992^{\circ}$ & $0.686^{*}$ & & \\
\hline 1993 & $0.880 * *$ & & \\
\hline $1991-92$ & $1.502^{* *}$ & 3.859 & 0.064 \\
\hline \multicolumn{4}{|c|}{ Dry matter yield $\left(\mathrm{kg} \mathrm{ha}^{-1}\right)$} \\
\hline 1991 & 7524 & & \\
\hline 1992 & 584276 & & \\
\hline 1993 & $901430 * *$ & & \\
\hline $1991-93$ & 717476 & $289343785^{* *}$ & $387878^{*}$ \\
\hline \multicolumn{4}{|l|}{ Plant height (cm) } \\
\hline 1991 & $126.84^{* *}$ & & \\
\hline 1992 & $250.82^{* *}$ & & \\
\hline 1993 & $205.83^{* *}$ & & \\
\hline $1991-93$ & $480.86^{* *}$ & $1617^{\star * *}$ & 51.31 \\
\hline \multicolumn{4}{|l|}{ Leaf width $(\mathrm{cm})$} \\
\hline 1991 & $0.0069 * *$ & & \\
\hline 1993 & $0.0145^{* *}$ & & \\
\hline $1991-93$ & $0.0183^{* *}$ & $0.4514^{* *}$ & $0.0031^{*}$ \\
\hline \multicolumn{4}{|l|}{ Leaf length $(\mathrm{cm})$} \\
\hline 1991 & $14.103^{* *}$ & & \\
\hline 1993 & $23.334^{* *}$ & & \\
\hline $1991-93$ & $34.174 * *$ & $830.04^{* *}$ & $3.2627^{*}$ \\
\hline
\end{tabular}


Table 4. Carbon isotope discrimination $(\Delta)$, dry matter yield, plant height, leaf width, and leaf length of 10 tetraploid ( $4 x$ ) accessions and 4 strains and cultivars of Russian wildrye, Experiment B.

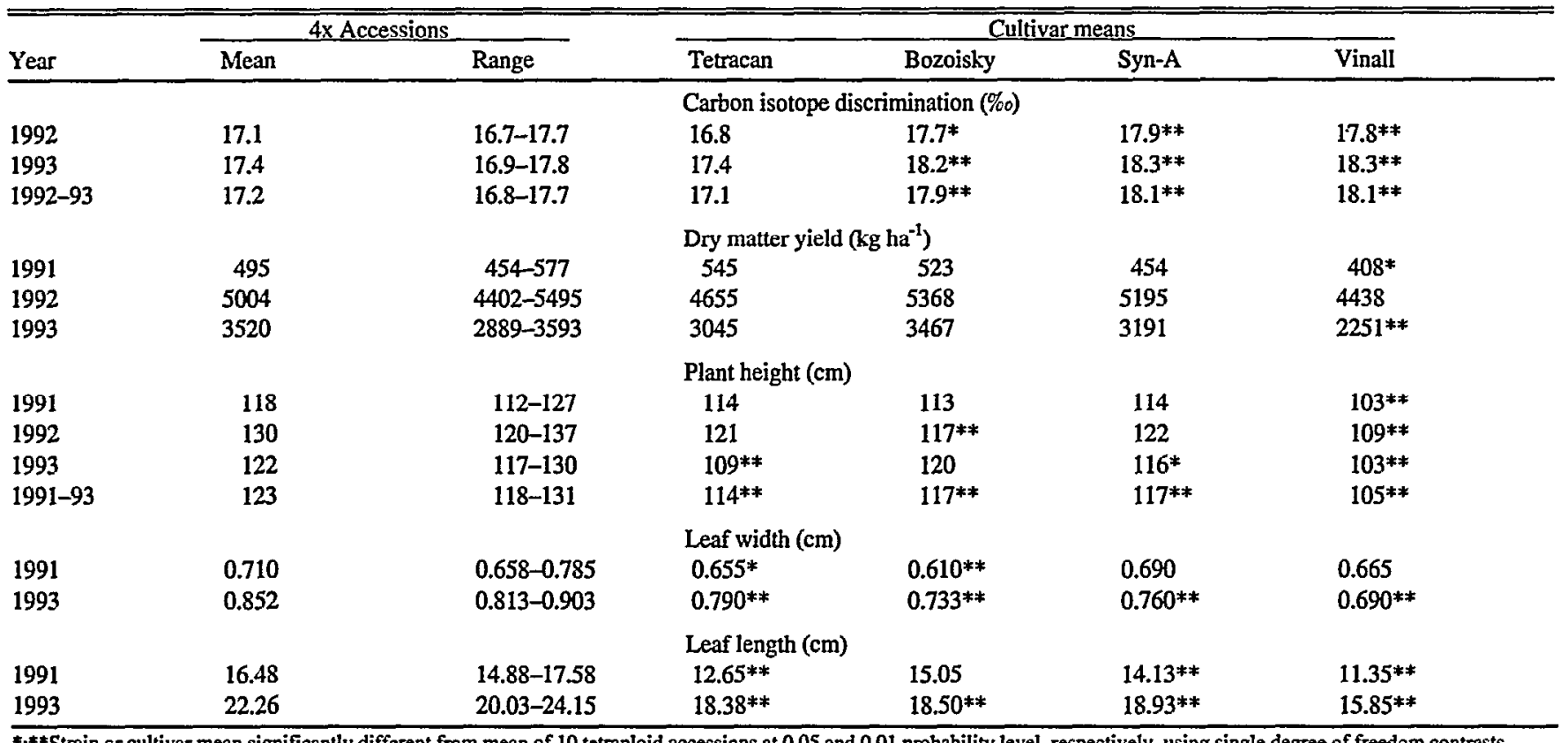

*,**Strain or cultivar mean significantly different from mean of 10 tetraploid accessions at 0.05 and 0.01 probability level, respectively, using single degree of freedom contrasts.

wildrye with less emphasis on evaluating the effects of induced polyploidy per se. However, when considered with previous findings by Berdahl and Barker (1991) and Lawrence et al. (1990), it is evident that tetraploids have distinct advantages compared to diploids in Russian wildrye, and tetraploid germplasm should be given high priority in future breeding programs with this species. Our results indicate that tetraploid accessions have larger seeds and better seedling vigor than presently available diploid cultivars, and that additional screening and selection within this germplasm pool should generate cultivars that are easier to establish on range sites. Although the drought response of these plant materials is yet to be fully assessed, our results based on carbon isotope discrimination indicate that tetraploids make more efficient use of water than the diploids included in our studies. This is an extremely important consideration in water-limited environments where Russian wildrye is most often used. The tetraploid accessions did not offer any consistent advantages over the diploids in terms of dry matter yield. It is noteworthy, however, that the diploid check entries were all improved cultivars, and it is likely that selection within the tetraploid germplasm pool would be effective in improving dry matter yield.

Until recently, no natural tetraploids of Russian wildrye had been introduced into North America. The exact origins of the entries included in this study are somewhat obscure; however, they are reportedly natural tetraploids. Natural tetraploids were also collected by 2 of the authors (Asay and Johnson) on rangeland sites in Kazakhstan in 1992. Tetraploid germplasm will be prominent in future Russian wildrye breeding programs, and research is needed to determine the relative frequency and distribution of diploid and tetraploid ecotypes in their natural settings.

\section{Literature Cited}

Asay, K.H. 1992. Breeding potentials in perennial Triticeae grasses. Hereditas 116: 167-173.

Asay, K.H., D.R. Dewey, F.B. Gomm, D.A. Johnson, and J. R. Carlson. 1985. Registration of 'Bozoisky-Select' Russian wildrye. Crop Sci. 25:575-576.
Asay, K.H. and D.A. Johnson. 1980. Screening for improved stand establishment in Russian wild ryegrass. Can. J. Plant Sci. 60:1171-1177.

Berdahl, J.D. and R.E. Barker. 1984. Selection for improved seedling vigor in Russian wild ryegrass. Can. J. Plant Sci. 64:131-138.

Berdahl, J.D. and R.E. Barker. 1991. Characterization of autotetraploid Russian wildrye produced with nitrous oxide. Crop Sci. 31:1153-1155.

Bingham, E.T., R.W. Groose, D.R. Woodfield, and K.K. Kidwell. 1994 Complementary gene interactions in alfalfa are greater in autotetraploids than diploids. Crop Sci. 34:823-829.

Dewey, D.R. 1980. Some applications and misapplications of induced polyploidy to plant breeding. p. 445-470 In: W.H. Lewis (ed.) Polyploidy: Biological relevance, Plenum Publ. Corp., N.Y.

Farquhar, G.D., J.R. Ehleringer, and K.T. Hubick. 1989. Carbon isotope discrimination and photosynthesis. Annu. Rev. Plant Physiol. Plant Mol. Biol. 40:503-537.

Hanson, A.A. 1972. Grass varieties in the United States. U. S. Dept. Agric. Handb. 170. U. S. Govt. Printing Office, Washington, D.C.

Jefferson, P.G. 1993. Seedling growth analysis of Russian wildrye. Can. J. Plant Sci. 73:1009-1015.

Johnson, D.A., K.H. Asay, L.L. Tieszen, J.R. Ehleringer, and P.G. Jefferson. 1990. Carbon isotope discrimination: Potential in screening coolseason grasses for water-limited environments. Crop Sci. 30:338-343.

Knipfel, J.E. and D.H. Heinrichs. 1978. Nutritional quality of crested wheatgrass, Russian wild ryegrass, and Altai wild ryegrass throughout the grazing season in southwestem Sask. Can. J. Plant Sci. 58:581-582.

Lawrence, T. 1979. Swift, Russian wild ryegrass. Can. J. Plant Sci. 59:515-518.

Lawrence, T., A.E. Slinkard, C.D. Ratzlaff, N.W. Holt, and P.G. Jefferson. 1990. Tetracan, Russian wild ryegrass. Can. J. Plant Sci. 70:311-313.

Maguire, J.D. 1962. Speed of germination - aid in selection and evaluation for seedling emergence and vigor. Crop Sci. 2:176-177.

Marten, G.C., J.S. Shenk, and F.E. Barton II. 1989. Near infrared reflectance spectroscopy (NIRS): Analysis of forage quality. ARS Agr. Handb. 643, U.S. Gov. Print. Off., Washington, D.C.

Read, J.J., D.A. Johnson, K.H. Asay, and L.L. Tieszen. 1992. Carbon isotope discrimination: Relationship to yield, gas exchange, and water-use efficiency in field-grown crested wheatgrass. Crop Sci. 32:168-175.

Rogler, G.A. and H.M. Schaaf. 1963. Growing Russian wildrye in the westem states. USDA Leaflet 313. U.S. Govt. Printing Office, Washington, D.C.

Sullivan, J.T. 1944. Further comparisons of plants with different chromosome numbers in respect to chemical composition. J. Am. Soc. Agron. $36: 537-543$ 